\title{
Carbon budgets of two typical polyculture pond systems in coastal China and their potential roles in the global carbon cycle
}

\author{
Dongxu Zhang ${ }^{1}$, Xiangli Tian ${ }^{1, *}$, Shuanglin Dong ${ }^{1}$, Yan Chen ${ }^{2}$, Jie Feng ${ }^{1}$, \\ Rui-Peng $\mathrm{He}^{1}$, Kai Zhang ${ }^{3}$
}

${ }^{1}$ The Key Laboratory of Mariculture (Ocean University of China), Ministry of Education, Qingdao 266003, PR China
${ }^{2}$ Beijing Aquatic Product Technology Promotion Department, Beijing 100029, PR China
${ }^{3}$ Pearl River Fisheries Research Institute, Chinese Academy of Fishery Science, Guangzhou 510380, PR China

\begin{abstract}
The role of aquaculture systems in the global carbon cycle is poorly understood to date. We investigated the carbon budgets in 2 polyculture systems (PM: swimming crab Portunus trituberculatus with kuruma shrimp Marsupenaeus japonicus; and PMR: crab, shrimp and shortnecked clam Ruditapes philippinarum) during the farming season (125 d in total). The main carbon input occurred via water (PM: 55.06\%; PMR: $62.50 \%$ ), followed by that via feed. PM absorbed $21.55 \mathrm{~g} \mathrm{C} \mathrm{m}^{-2}$ across the air-water interface, accounting for $13.27 \%$ of the total input. The carbon output via water was the main output in both PM (89.17\%) and PMR (46.43\%). PMR emitted $53.00 \mathrm{~g} \mathrm{C} \mathrm{m}^{-2}$ into the atmosphere during the farming season, accounting for $32.53 \%$ of the total output. The carbon output by harvested animals in PMR accounted for $19.48 \%$ of the total output, which was much higher than that in PM $(5.71 \%)$. Carbon accumulation in the sediment was significantly higher in PM than in PMR $(p<0.05)$, but the value of both represented a small portion of the total output. Clam farming in the polyculture system profoundly altered the carbon budgets by changing the $\mathrm{CO}_{2}$ flux direction, reducing carbon accumulation in water and sediments and increasing the carbon output by harvested animals. In terms of the global warming potential, which was calculated from the results of $\mathrm{CO}_{2}$ and $\mathrm{CH}_{4}$ fluxes across the air-water interface, $\mathrm{PM}$ had the potential for mitigating the greenhouse effect on the $20 \mathrm{yr}$ horizon, whereas PMR exacerbated global warming. Our results suggest that PM acted as a net carbon sink in the global carbon cycle, while PMR acted as a carbon source.
\end{abstract}

KEY WORDS: Polyculture - Carbon budget - Clam farming - Global warming potential · Carbon sink/source function

\section{INTRODUCTION}

Carbon dioxide $\left(\mathrm{CO}_{2}\right)$ and methane $\left(\mathrm{CH}_{4}\right)$ are the 2 main greenhouse gases contributing to global warming. According to the latest reporting, the atmospheric concentrations of $\mathrm{CO}_{2}$ and $\mathrm{CH}_{4}$ reached new highs in 2016, with $\mathrm{CO}_{2}$ at $403.3 \mathrm{ppm}$ and $\mathrm{CH}_{4}$ at $1.853 \mathrm{ppm}$, representing 145 and $257 \%$ of the preindustrial levels, respectively (WMO 2017). As the $\mathrm{CO}_{2}$ and $\mathrm{CH}_{4}$ concentrations in the atmosphere in-

\footnotetext{
${ }^{*}$ Corresponding author: xianglitian@ouc.edu.cn
}

crease continuously, issues in the global carbon cycle have been a research hotspot. During the past decades, concerns about global warming and its potentially serious consequences have prompted a number of studies on the carbon sink/source function of terrestrial and aquatic ecosystems (e.g. Dixon et al. 1994, Muller-Karger et al. 2005, Cole et al. 2007, Tranvik et al. 2009, Pan et al. 2011).

Aquatic ecosystems are important parts of the global carbon cycle. Oceans are generally regarded as the

(C) The authors 2020. Open Access under Creative Commons by Attribution Licence. Use, distribution and reproduction are unrestricted. Authors and original publication must be credited. 
most important player in the global carbon cycle. Oceans could absorb 2.6 $\mathrm{Pg} \mathrm{C} \mathrm{yr}{ }^{-1}$, which is approximately $26 \%$ of the annual carbon emissions from $\mathrm{CO}_{2}$ (Le Quéré et al. 2017), and ocean margins account for approximately $50 \%$ of the total absorption (Cai et al. 2006). Additionally, the annual $\mathrm{CH}_{4}$ emission by oceans was estimated to be 10.9-17.8 Tg (Bange et al. 1994, Ortiz-Llorente \& Alvarez-Cobelas 2012). Inland waters are considered to be potential sources of $\mathrm{CO}_{2}$ and $\mathrm{CH}_{4}$. Global inland water emits an estimated 2.1 $\mathrm{Pg} \mathrm{C} \mathrm{yr}{ }^{-1}$ by $\mathrm{CO}_{2}$ emission (Raymond et al. 2013) and $0.08 \mathrm{Pg} \mathrm{C} \mathrm{yr}^{-1}$ by $\mathrm{CH}_{4}$ emission (Bastviken et al. 2011). As sedimentary environments, aquatic ecosystems can sequester carbon by burial in the sediment, thus affecting the global carbon cycle. According to an estimation by MullerKarger et al. (2005), at least $0.06 \mathrm{Pg} \mathrm{C} \mathrm{yr}^{-1}$ may be buried in sediments in coastal areas. Inland waters could bury $0.23 \mathrm{Pg} \mathrm{C} \mathrm{yr}^{-1}$, mainly in lakes and reservoirs (Cole et al. 2007).

Aquaculture systems are artificial aquatic ecosystems. The global aquaculture pond area was estimated to be $1.1 \times 10^{5} \mathrm{~km}^{2}$, with that of China covering approximately $6.3 \times 10^{4} \mathrm{~km}^{2}$, which accounts for nearly $56 \%$ of the global aquaculture pond area (Verdegem \& Bosma 2009). Although the global aquaculture pond area is much smaller than that of other aquatic ecosystems such as lakes and reservoirs (Raymond et al. 2013), aquaculture systems usually involve various forms of artificial management such as stocked animals, feeding, water exchange, harvesting, etc. As a consequence, the involved biogeochemical processes might be more complicated and usually vary among different aquaculture systems, which could eventually affect the role that aquaculture systems play in the global carbon cycle. Currently, studies on the carbon cycle of aquaculture systems mainly focus on organic carbon. Researchers are mostly concerned with the carbon utilization efficiency, the carbon accumulation in the systems and the effluents into adjacent waters during the farming season, which could provide references for practical aquaculture activities and eventually achieve sustainable development for the aquaculture industry (Adhikari et al. 2012, Sahu et al. 2013a,b, J. Li et al. 2015, Zhang et al. 2016). However, to date, studies on the assessment of the carbon sink/source function of aquaculture systems in the global carbon cycle are still limited.

The swimming crab Portunus trituberculatus has been widely cultured on the coast of China, and production of this species reached a new high in 2016, at 125317 t (Fisheries Department of Agriculture Ministry of China 2017). Multi-species polyculture is well established in China and exhibits better economic benefits and ecological efficiency than monoculture (Tian et al. 2001, Zhang et al. 2016). The swimming crab is a very popular species in polyculture systems, and the polyculture of swimming crabs with shrimp and clams are the 2 most common combinations used in polyculture systems (Dong et al. 2013). In the present study, we selected 2 typical polyculture systems: a polyculture of swimming crab with kuruma shrimp Marsupenaeus japonicus (PM) and a polyculture of swimming crab with kuruma shrimp and short-necked clam Ruditapes philippinarum (PMR), and the carbon budgets of the polyculture systems during the farming season were studied. The aims of this study were: (1) to assess the carbon budgets of the 2 polyculture systems and the differences between them and (2) to evaluate the potential role of aquaculture systems in the global carbon cycle. We calculated global warming potential (GWP), which is the time-integrated radiative forcing due to a pulse emission of a given gas over a given time horizon relative to a pulse emission of $\mathrm{CO}_{2}$ (Shine et al. 2005), to compare the potential climate impact of emissions of different greenhouse gases (IPCC 2014).

\section{MATERIALS AND METHODS}

\subsection{Experimental ponds}

The study was conducted in the Modern Agriculture Industrial Park in Ganyu County, Jiangsu Province, China $\left(34.97^{\circ} \mathrm{N}, 119.20^{\circ} \mathrm{E}\right)$, which represents a temperate monsoonal climate, from July to November 2014 using the PM and PMR systems described above. Three ponds were sampled for each system, and all ponds were oriented north-south $(170.0 \mathrm{~m}$ length $\times 60.0 \mathrm{~m}$ width $\times 2.3 \mathrm{~m}$ depth). In both $\mathrm{PM}$ and PMR, crabs were stocked at 7.2 ind. $\mathrm{m}^{-2}$ and shrimp were stocked at 48.0 ind. $\mathrm{m}^{-2}$. Clams were stocked at 50.0 ind. $\mathrm{m}^{-2}$ in PMR. The initial mean individual weights of crabs, shrimp and clams were 0.042, 0.013 and $0.20 \mathrm{~g}$, respectively. During the farming season, live blue clams Aloidis laevis were supplied twice per day as a food source, and the ponds were supplemented with frozen rough fish when blue clams were not available. The input amounts of A. laevis and frozen fish were 28.5 and $3.8 \mathrm{t}$ during the farming season, respectively. The seawater in the ponds was routinely exchanged through water inlets and outlets during spring tides. 


\subsection{Water quality}

In total, 9 water samples (samples of the surface, middle and bottom water layers at 3 different sites) were taken from each pond with a horizontal sampler (JC-800D, Juchuang). Water temperature and dissolved oxygen (DO) content were measured with a YSI instrument (5000-230V), and the water $\mathrm{pH}$ was determined with an acidometer (PHS-3C, Shanghai REX Instruments). Water samples were stored separately in 11 polyethylene bottles and then immediately taken to the laboratory. Nitrate nitrogen $\left(\mathrm{NO}_{3}{ }^{-}-\mathrm{N}\right)$ was determined by the cadmium-copper column reduction method according to Hansen \& Korolett (1999). Nitrite nitrogen $\left(\mathrm{NO}_{2}{ }^{-}-\mathrm{N}\right)$ was measured by the method described by Bendschneider \& Robinson (1952), and ammonia nitrogen $\left(\mathrm{NH}_{4}{ }^{+}-\mathrm{N}\right)$ was determined with the indophenol blue method according to Sagi (1966). Soluble reactive phosphorus $\left(\mathrm{PO}_{4}{ }^{3-}-\mathrm{P}\right)$ was analyzed following the method introduced by Murphy \& Riley (1962).

Measurements demonstrated that the water temperature ranged from $12.0-27.2^{\circ} \mathrm{C}$ during the farming season. Dissolved oxygen varied from 5.95-10.72 $\mathrm{mg} \mathrm{l}^{-1}$, and the water $\mathrm{pH}$ ranged from 7.78-8.80. The concentrations of $\mathrm{NO}_{3}{ }^{-}-\mathrm{N}, \mathrm{NO}_{2}{ }^{-}-\mathrm{N}, \mathrm{NH}_{4}{ }^{+}-\mathrm{N}$ and $\mathrm{PO}_{4}{ }^{3-}-\mathrm{P}$ fluctuated from $0.04-0.77,0.01-0.14,0.01-0.10$ and 0.01-0.05 $\mathrm{mg} \mathrm{l}^{-1}$, respectively, during the farming season.

\subsection{Carbon budget}

\subsubsection{Calculation of the carbon budget}

The carbon budgets of the polyculture systems were calculated according to the mass balance. The carbon inputs included stocked animals, feed, water, precipitation and $\mathrm{CO}_{2} / \mathrm{CH}_{4}$ absorbed across the waterair interface. The carbon outputs were mainly from the harvest of cultured animals, sediment accumulation, water and $\mathrm{CO}_{2} / \mathrm{CH}_{4}$ emission from the water column. We used the following equation:

$$
\begin{gathered}
W_{0}+F_{\text {in }}+W_{\text {in }}+P_{\text {in }}+C A_{\text {in }}=W_{\mathrm{t}}+W_{\text {out }}+F_{\mathrm{CH} 4}+F_{\mathrm{CO} 2}+ \\
C A_{\text {out }}+S T_{\text {out }}
\end{gathered}
$$

where $W_{0}$ represents the initial amount of carbon in the water column; $F_{\text {in }}$ is the amount of carbon in the feed; $W_{\text {in }}$ is the amount of carbon input into the system via water inflow; $P_{\text {in }}$ is the amount of carbon input through precipitation; $C A_{\text {in }}$ is the amount of carbon in stocked animals; $W_{\mathrm{t}}$ is the amount of carbon in the water column at the end of the experi- ment; $W_{\text {out }}$ is the amount of carbon output from the system via water discharge $F_{\mathrm{CH} 4}$ and $F_{\mathrm{CO} 2}$ are the balance of the carbon amounts absorbed by the water column and released into the atmosphere across the water-air interface in the form of $\mathrm{CH}_{4}$ and $\mathrm{CO}_{2}$, respectively, and positive values of these variables represent carbon absorption by the water column, while negative values indicate carbon emissions from the water column; $C A_{\text {out }}$ is the amount of carbon in harvested animals; and $S T_{\text {out }}$ is the amount of carbon accumulated in the sediment.

\subsubsection{Determination of samples}

The $\mathrm{CH}_{4} / \mathrm{CO}_{2}$ fluxes across the water-air interface were determined using a static chamber technique (Chen et al. 2015, 2016) with a sampling interval of approximately $15 \mathrm{~d}$. In total, 9 samplings were conducted during the farming season. Three chambers were deployed into each pond for collecting gas samples. For each sampling, 4 gas samples of $100 \mathrm{ml}$ were transferred from the chamber into the vacuum sampling bags via polypropylene syringes at 0,10 , 20 and $30 \mathrm{~min}$ after deployment. Gas samples were stored at $4{ }^{\circ} \mathrm{C}$ and then transported to the laboratory. The gas samples were analyzed as soon as possible with a GC-2010 Plus gas chromatograph (Shimadzu) connected to an MGS-4 gas sampler and an MTN-1 methanizer. After being driven into the MGS-4 gas sampler, $\mathrm{CH}_{4}$ and $\mathrm{CO}_{2}$ were separated on the column $\left(2 \mathrm{~m} \times 2 \mathrm{~mm}\right.$ stainless steel, $40^{\circ} \mathrm{C}$, packed with TDX [60-80 mesh]). $\mathrm{CH}_{4}$ was then determined with a flame ionization detector (FID) at $100^{\circ} \mathrm{C}$. The separated $\mathrm{CO}_{2}$ was converted into $\mathrm{CH}_{4}$ in the MTN-1 methanizer by a nickel catalyst at $375^{\circ} \mathrm{C}$ and was then determined with a FID detector at $100^{\circ} \mathrm{C}$. $\mathrm{CO}_{2}$ and $\mathrm{CH}_{4}$ fluxes were calculated from the linear regression of the changes in $\mathrm{CO}_{2}$ and $\mathrm{CH}_{4}$ concentrations over time. The amount of carbon exchange across the water-air interface in the form of $\mathrm{CH}_{4}$ and $\mathrm{CO}_{2}$ during the farming season calculated as:

$$
\begin{gathered}
\text { Carbon amount }\left(\mathrm{g} \mathrm{m}^{-2}\right)= \\
\text { average flux }{ }_{\mathrm{CH} 4 / \mathrm{CO} 2}\left(\mathrm{~g} \mathrm{~m}^{-2} \mathrm{~d}^{-1}\right) \times \text { farming duration (d) } \\
\times \mathrm{M}_{\mathrm{C}}\left(\mathrm{g} \mathrm{mol}^{-1}\right) / \mathrm{M}_{\mathrm{CH} 4}\left(\mathrm{M}_{\mathrm{CO} 2}\right)\left(\mathrm{g} \mathrm{mol}^{-1}\right)
\end{gathered}
$$

where $\mathrm{M}_{\mathrm{C}}, \mathrm{M}_{\mathrm{CH} 4}$ and $\mathrm{M}_{\mathrm{CO} 2}$ represent the relative molecular weights of carbon, $\mathrm{CH}_{4}$ and $\mathrm{CO}_{2}$, respectively.

The amounts of carbon input into or output from the systems through feed, animals, water and rain during the farming season were calculated as: 
Carbon in feed/animals/water/rain $\left(\mathrm{g} \mathrm{m}^{-2}\right)=$ carbon concentration in feed/animals/water/rain (g per $g$ dry matter or 1 ) $\times$ total amount of feed/animals/water/rain (g dry matter or 1$) \div$ pond area $\left(\mathrm{m}^{2}\right)$

At the beginning of the farming season, samples of stocked animals were collected, and the stocking biomass was recorded. After the animals were harvested, samples of cultured animals were collected from each pond, and the harvested biomass was also recorded. The feeds applied during the farming season were collected, and the feed amounts were recorded daily. The stocked and harvested animals as well as the feeds were dried at $60^{\circ} \mathrm{C}$ to a constant weight, ground and sieved with a sample sifter (pore size $0.15 \mathrm{~mm}$ ). The carbon contents of the samples were determined by a Vario ELIII elemental analyzer (Elementar).

During each spring tide, inflow and discharge water samples were collected repeatedly and pooled into 1 sample, and the amount of inflow water and discharge water was measured by a flow velocity meter (LS-1206B, Haosheng Industry and Trade). The water samples were stored in clean plastic bottles and then immediately transported to the laboratory. The concentrations of particulate organic carbon (POC), dissolved organic carbon (DOC) and dissolved inorganic carbon (DIC) in the water samples were determined to calculate the carbon amount in the water. The POC concentration was measured by the Vario ELIII elemental analyzer. For this procedure, $25 \mathrm{ml}$ water samples were first filtered through preweighed Whatman $\mathrm{GF} / \mathrm{F}$ filters $\left(450^{\circ} \mathrm{C}\right.$ pre-combusted), and then the filters were acidized for $4 \mathrm{~h}$ with $1 \mathrm{M} \mathrm{HCl}$ to remove the carbonate. The DOC and DIC contents in the water samples were analyzed in the above filter liquor by using the multi-2100s TOC analyzer (Analytik Jena).

Rain was collected in beakers $\left(450^{\circ} \mathrm{C}\right.$ precombusted) and quantified by a rain gauge (HYDZ). The carbon contents of the rain were determined by the same method used for the water samples.

Sediment $(0-10 \mathrm{~cm})$ was sampled using a cylindrical metal corer (diameter $8 \mathrm{~cm}$ ) with a sampling interval of approximately $15 \mathrm{~d}$. The sediment samples were immediately transported to the laboratory and weighed to calculate the density. The sediment samples were then dried to constant weights at $60^{\circ} \mathrm{C}$, and the moisture content of the sediment was calculated from the weight loss. The carbon content was also determined by the Vario ELIII elemental analyzer after the dry sediment samples were ground and sieved with a sample sifter (pore size $0.15 \mathrm{~mm}$ ). Carbon storage in the sediment during the farming season was calculated as:

$$
\begin{aligned}
& \text { Carbon storage in sediment }\left(\mathrm{g} \mathrm{m}^{-2}\right)= \\
& \text { carbon concentration in sediment }\left(\mathrm{g} \mathrm{g}^{-1} \text { dry matter }\right) \times \\
& \text { sediment density }\left(\mathrm{g} \mathrm{cm}^{-3}\right) \times \text { sediment volume }(\mathrm{l}) \times \\
& (1-\text { sediment moisture content }(\%)) / \text { pond area }\left(\mathrm{m}^{2}\right) \times 1000
\end{aligned}
$$

The carbon accumulation in the sediment was derived from the difference between carbon storage in the sediment at the beginning and the end of the experiment.

\subsection{GWP}

To calculate GWP, we applied values of 1 for $\mathrm{CO}_{2}$ and 84 for $\mathrm{CH}_{4}$ (IPCC 2014) over $20 \mathrm{yr}$.

\subsection{Statistical analysis}

All values are presented as means \pm SD. The data were analyzed with the statistical software SPSS 17.0. The data normality and the homogeneity of variances were checked using KolmogorovSmirnov and Levene's tests, respectively. Both assumptions were met by the data. The $t$-test was used to determine the differences between PM and PMR. Results were considered significant at $\mathrm{p}<0.05$.

\section{RESULTS}

\subsection{Harvest of cultured animals}

As shown in Table 1, no significant difference in the yields of swimming crabs and kuruma shrimp was found between PM and PMR ( $p>0.05, t_{4}=-1.059$ for shrimp, $t_{4}=1.806$ for crabs).

Table 1. Yield information $\left(\mathrm{g} \mathrm{m}^{-2}\right)$ of animals cultured in 2 polyculture systems. PM: Swimming crabs with kuruma shrimp; PMR: swimming crabs with kuruma shrimp and short-necked clams. Values are means \pm SD $(\mathrm{n}=3)$

\begin{tabular}{|cccc|}
\hline $\begin{array}{c}\text { Farming } \\
\text { system }\end{array}$ & $\begin{array}{c}\text { Swimming } \\
\text { crabs }\end{array}$ & $\begin{array}{c}\text { Kuruma } \\
\text { shrimp }\end{array}$ & $\begin{array}{c}\text { Short-necked } \\
\text { clams }\end{array}$ \\
\hline PM & $75.83 \pm 1.52$ & $30.33 \pm 1.53$ & Not stocked \\
PMR & $85.00 \pm 8.66$ & $28.33 \pm 2.89$ & $186.67 \pm 18.93$ \\
\hline
\end{tabular}




\subsection{Carbon budgets}

The main carbon inputs in the 2 systems are listed in Table 2. Water inflow during the farming season was the main input item, accounting for 37.01 and $41.86 \%$ in $\mathrm{PM}$ and PMR, respectively, which was followed by feeds and the water column. In PM, carbon input through $\mathrm{CO}_{2}$ absorption across the water-air interface was an important input source, accounting for $13.27 \%$. Cultured animals and precipitation, which represented small parts of the carbon input, accounted for 0.03 and $1.01 \%$ in PM and 0.86 and $1.11 \%$ in PMR.

Information on carbon outputs is provided in Table 3. In PM, water discharge and the water column were the main output items, accounting for 48.99 and $40.18 \%$, respectively. The carbon outputs in the form of harvested animals, $\mathrm{CH}_{4}$ emissions and sediment accumulation represented small parts, accounting for only $5.71,0.10$ and $5.02 \%$, respectively.

Table 2. Carbon input in the 2 polyculture systems (PM and PMR, defined in Table 1$)$ during the farming season. The values for mass are means $\pm \operatorname{SD}(n=3)$ and the values for proportion are presented as means $(n=3)$. Data in the same row with different superscripts indicate significant differences $(p<0.05)$

\begin{tabular}{|cccccc|}
\hline & \multicolumn{3}{c}{$\mathrm{PM}$} & & \multicolumn{2}{c|}{ PMR } \\
\cline { 2 - 3 } \cline { 5 - 6 } Item & Mass $\left(\mathrm{g} \mathrm{m}^{-2}\right)$ & Proportion $(\%)$ & & Mass $\left(\mathrm{g} \mathrm{m}^{-2}\right)$ & Proportion (\%) \\
\hline Crab & 0.016 & 0.01 & & 0.016 & 0.01 \\
Shrimp & 0.034 & 0.02 & & 0.034 & 0.02 \\
Clam & - & - & & 1.22 & 0.83 \\
Feed & $49.75 \pm 2.89$ & 30.63 & & $52.12 \pm 1.85$ & 35.51 \\
Precipitation & 1.64 & 1.01 & & 1.64 & 1.11 \\
Water column & $29.32 \pm 2.02$ & 18.05 & & $30.30 \pm 1.67$ & 20.64 \\
Water inflow & $60.12 \pm 1.54$ & 37.01 & & $61.43 \pm 2.18$ & 41.86 \\
$\mathrm{CO}_{2}$ absorption & $21.55 \pm 6.57$ & 13.27 & & - & - \\
Total input & $162.43 \pm 5.62^{\mathrm{a}}$ & & $146.76 \pm 3.17^{\mathrm{b}}$ & \\
\hline
\end{tabular}

Table 3. Carbon output in the 2 polyculture systems (PM and PMR, defined in Table 1) during the farming season. The values for mass are means $\pm \operatorname{SD}(n=3)$ and the values for proportion are presented as means $(n=3)$. Data in the same row with different superscripts indicate significant differences $(p<0.05)$

\begin{tabular}{|cccccc|}
\hline & \multicolumn{3}{c}{$\mathrm{PM}$} & & \multicolumn{2}{c|}{ PMR } \\
\cline { 2 - 3 } \cline { 5 - 6 } Item & Mass $\left(\mathrm{g} \mathrm{m}^{-2}\right)$ & Proportion $(\%)$ & & Mass $\left(\mathrm{g} \mathrm{m}^{-2}\right)$ & Proportion (\%) \\
\hline Crab & $5.59 \pm 0.11$ & 3.72 & & $6.26 \pm 0.64$ & 3.84 \\
Shrimp & $2.99 \pm 0.15$ & 1.99 & & $2.80 \pm 0.75$ & 1.72 \\
Clam & - & - & & $22.67 \pm 2.30$ & 13.92 \\
Water column & $60.33 \pm 3.34^{\mathrm{a}}$ & 40.18 & & $33.21 \pm 1.91^{\mathrm{b}}$ & 20.38 \\
Water discharge & $73.55 \pm 2.80^{\mathrm{a}}$ & 48.99 & & $42.44 \pm 2.65^{\mathrm{b}}$ & 26.05 \\
$\mathrm{CO}_{2}$ emission & - & - & & $53.00 \pm 8.00$ & 32.53 \\
$\mathrm{CH}_{4}$ emission & $0.14 \pm 0.02$ & 0.10 & & $0.15 \pm 0.02$ & 0.09 \\
Sediment & $7.54 \pm 0.56^{\mathrm{a}}$ & 5.02 & $2.40 \pm 0.37^{\mathrm{b}}$ & 1.47 \\
accumulation & & & & & \\
Total output & $150.13 \pm 3.27^{\mathrm{b}}$ & & & & \\
\end{tabular}

In $\mathrm{PMR}, \mathrm{CO}_{2}$ emission across the water-air interface was the largest output item, accounting for $32.53 \%$, which was followed by water discharge and the water column. The carbon output by clam harvesting was the biggest contributor among the harvested animals. $\mathrm{CH}_{4}$ emissions and sediment accumulation both represented small parts, accounting for 0.09 and $1.47 \%$, respectively.

\subsection{Carbon input/output via the water column and water exchange}

Fig. 1 shows the amount of carbon input and output in the aquaculture systems via the water column ifferences between the input amounts of DIC, $C$ were observed between the 2 polyculture systems $\left(p>0.05, t_{4}=-2.042\right.$ for DIC, $t_{4}=-0.539$ for DOC, $t_{4}=-0.191$ for POC). In terms of the output carbon, the amounts of DIC, POC and DOC via water in PM were 109.33, 14.64 and $9.90 \mathrm{~g} \mathrm{~m}^{-2}$, respectively, which were all higher than the input amounts. Conversely, the output amounts of DIC, POC and DOC via water in PMR were 67.99, 7.26 and $1.40 \mathrm{~g} \mathrm{~m}^{-2}$, respectively, which were all lower than the input amounts.

\section{4. $\mathrm{CO}_{2}$ and $\mathrm{CH}_{4}$ fluxes and GWP}

As shown in Fig. 2, on the whole, $\mathrm{PM}$ acted as a $\mathrm{CO}_{2}$ sink, with the $\mathrm{CO}_{2}$ flux ranging from -70.50 to $40.55 \mathrm{mg} \mathrm{m}^{-2} \mathrm{~h}^{-1}$ (mean: $-27.43 \mathrm{mg} \mathrm{m}^{-2} \mathrm{~h}^{-1}$ ), while PMR acted as a stable $\mathrm{CO}_{2}$ source, with the $\mathrm{CO}_{2}$ flux ranging from 24.63 to $97.62 \mathrm{mg} \mathrm{m}^{-2} \mathrm{~h}^{-1}$ (mean: $67.45 \mathrm{mg} \mathrm{m}^{-2} \mathrm{~h}^{-1}$ ). The $\mathrm{PM}$ and PMR culture systems both acted as stable $\mathrm{CH}_{4}$ sources for the atmosphere, with average fluxes of 66.0 and $68.7 \mu \mathrm{g} \mathrm{m}^{-2} \mathrm{~h}^{-1}$, respectively, and no difference was observed between them $\left(p>0.05, t_{16}=-0.142\right)$ (Zhang et al. 2019, Fig. 2).

$\mathrm{CO}_{2}$ and $\mathrm{CH}_{4}$ emissions, as well as their GWP, are shown in Table 4. During the farming season, PM absorbed $79.03 \mathrm{~g} \mathrm{CO}_{2} \mathrm{~m}^{-2}$ cumula- 


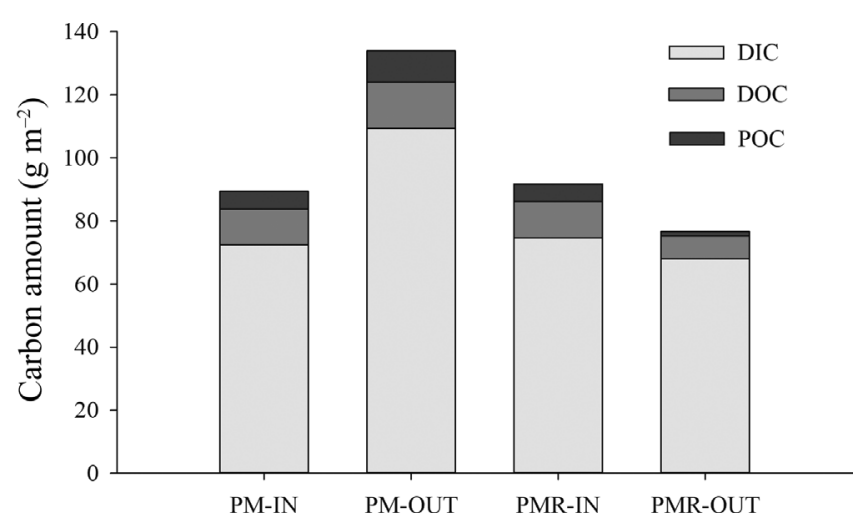

Fig. 1. Amount of dissolved inorganic carbon (DIC), dissolved organic carbon (DOC) and particulate organic carbon (POC) input into/output from the aquaculture systems via water. PM and PMR are defined in Table 1. IN represents input and OUT represents output of carbon in both systems
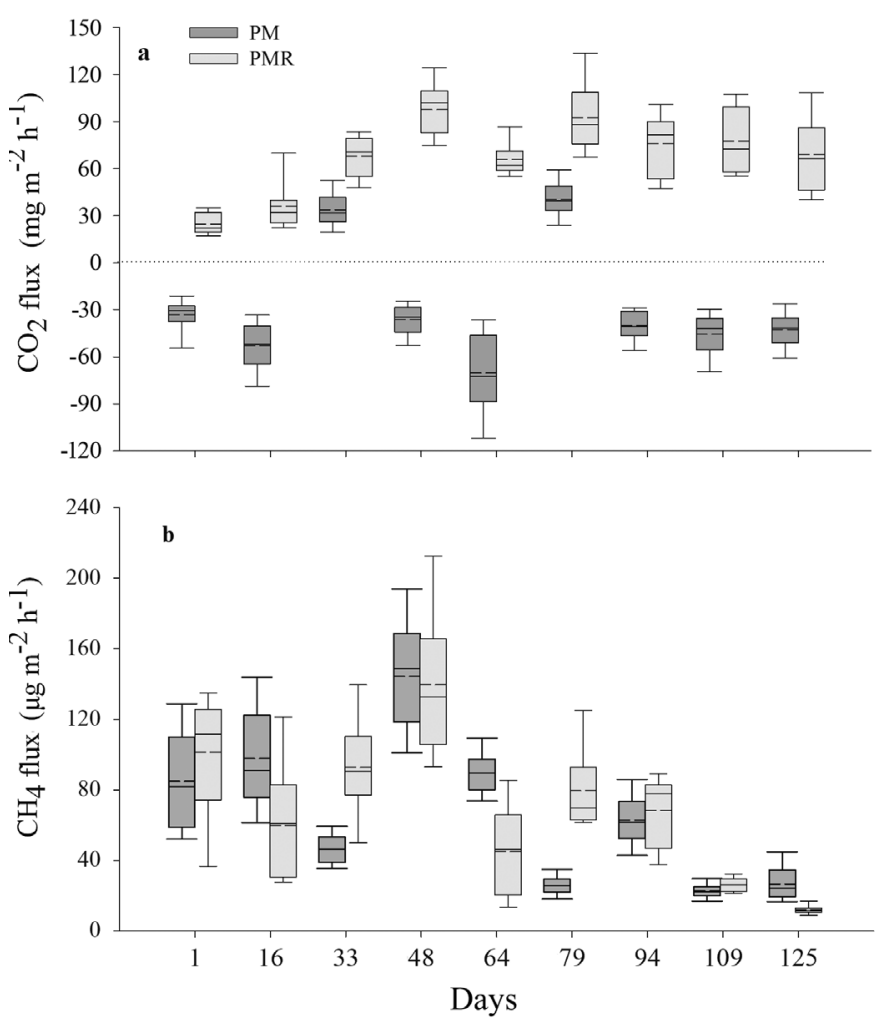

Fig. 2. Variations in (a) $\mathrm{CO}_{2}$ and (b) $\mathrm{CH}_{4}$ fluxes of the $\mathrm{PM}$ and PMR aquaculture systems (defined in Table 1) during the farming season. Boxes define the $25^{\text {th }}$ and $75^{\text {th }}$ percentiles, whiskers define the $5^{\text {th }}$ and $95^{\text {th }}$ percentiles, and solid and dashed horizontal lines show the median and mean values, respectively

tively, while PMR emitted $194.35 \mathrm{~g} \mathrm{CO}_{2} \mathrm{~m}^{-2}$. The $\mathrm{CH}_{4}$ emissions in PM and PMR were cumulatively $0.19 \mathrm{~g}$ $\mathrm{m}^{-2}$ and $0.20 \mathrm{~g} \mathrm{~m}^{-2}$, respectively, during the farming season. On the $20 \mathrm{yr}$ horizon, the comprehensive GWP (cGWP) value in PM was negative, which indi-
Table 4. Carbon emissions and global warming potential (GWP) in the 2 polyculture systems (PM and PMR, defined in Table 1) during the farming season. cGWP: comprehensive GWP. Values are means \pm SD $(n=3)$

\begin{tabular}{|cccc|}
\hline & & PM & PMR \\
\hline $\mathrm{CO}_{2}$ & Emission $\left(\mathrm{g} \mathrm{CO}_{2} \mathrm{~m}^{-2}\right)$ & $-79.03 \pm 24.08$ & $194.35 \pm 29.33$ \\
& $\mathrm{GWP}$ & $-79.03 \pm 24.08$ & $194.35 \pm 29.33$ \\
$\mathrm{CH}_{4}$ & Emission $\left(\mathrm{g} \mathrm{CH}_{4} \mathrm{~m}^{-2}\right)$ & $0.19 \pm 0.03$ & $0.20 \pm 0.02$ \\
& $\mathrm{GWP}$ & $15.98 \pm 2.57$ & $17.06 \pm 1.99$ \\
& $\mathrm{cGWP}$ & $-63.05 \pm 26.65$ & $211.41 \pm 31.30$ \\
\hline
\end{tabular}

cated that PM could mitigate global warming, while PMR showed a trend of accelerating global warming.

\section{DISCUSSION}

\subsection{Carbon budgets in PM and PMR}

Water exchange is normally applied routinely in coastal pond-aquaculture systems and is regarded as an important management method to stabilize water quality. In the present study, seawater in the ponds was routinely exchanged during spring tides. In terms of carbon budgets, the carbon input and output via water accounted for 55.06 and $89.17 \%$ in $\mathrm{PM}$ and 62.50 and $46.43 \%$ in PMR, representing the largest parts of the budgets. In general, organic carbon tends to accumulate in aquaculture wastewaters due to feed residue, the excretion and egestion of cultured animals, etc. during the farming process. However, according to Fig. 1, the amounts of POC and DOC output via water in PMR were both less than the input amounts, which may be related to the culturing of clams. On one hand, bivalves, as filterfeeders, are able to decrease the particulate matter concentration in the water column (Dame \& Prins 1997, Prins et al. 1997, Forrest et al. 2009, Sousa et al. 2009, Boltovskoy \& Correa 2015, Dame 2016). On the other hand, grazing activities by bivalves could stimulate the reproduction of the microbial community in the water column (Stabili et al. 2005, Tang et al. 2015), hence enhancing the consumption of DOC. In addition, the increasing water transparency resulting from filter-feeding by bivalves might be another reason for the DOC decline in PMR. Sunlight-driven degradation of organic matter seems to occur more easily in high-transparency waters (Hayakawa et al. 2003, Williamson et al. 2015).

As important types of aquaculture waste, feces and residual feed from farmed organisms are the main sources of waste accumulating on the sediment in 
intensive aquaculture systems (Sarà et al. 2004, Xia et al. 2014). In the present study, sediment accumulations in PM and PMR were 7.54 and $2.40 \mathrm{~g} \mathrm{~m}^{-2}$, respectively, during the farming season, which were much lower than those of the aquaculture systems reported by Alongi et al. (2000) and Zhang et al. (2016). These results suggested that PM and PMR might have produced less particle waste during the farming season. Live blue clams were supplied as the main food source both in PM and PMR. Crabs feed on blue clams and benthos, and shrimp feed on the residue of blue clams uneaten by crabs, as well as benthos. Bioturbation by the short-necked clam might be the main reason behind the difference in sediment accumulation between PM and PMR. The bioturbation of sediment through bivalve movements could increase the sediment water and oxygen content (Vaughn \& Hakenkamp 2001), as well as the resuspension of organic matter from the sediment (Davis 1993). All of these effects could facilitate the mineralization of organic carbon and, hence, reduce the accumulation of organic carbon in the sediment.

In aquaculture systems, organic carbon is the main carbon source for cultured animals to build up their bodies, and generally, the utilization rate is relatively low (Holmer et al. 2003). For example, harvested animals accounted for $0.86-3.44 \%$ in a tilapia culture system (Boyd et al. 2010) and accounted for $3.11-3.78 \%$ of the input carbon in a shrimp culture system (Adhikari et al. 2012). In our study, the harvested animals accounted for 5.29 and $21.61 \%$ of the carbon input in PM and PMR, respectively, which were higher values than those in the above studies. These results might be related to the different aquaculture models. Polyculture systems often have a higher utilization rate of the input carbon than do monoculture systems (Zhang et al. 2016). In PMR, in addition to organic carbon, inorganic carbon could also be used by the clams to build up their shells (Frankignoulle 1994, Frankignoulle et al. 1994). The harvesting of shells and soft tissue of clams contributed 13.58 and $1.86 \%$, respectively, to the utilization rate of input carbon. Therefore, clam farming could greatly increase the carbon utilization rate of aquaculture systems, especially due to inorganic carbon sequestration by bivalve shells.

\subsection{Ecological functions of short-necked clams}

According to Filgueira et al. (2015), bivalves can impact phytoplankton dynamics and benthic-pelagic coupling, which can significantly contribute to the $\mathrm{CO}_{2}$ cycle. Our results in Tables $2 \& 3$ show that $\mathrm{PM}$ absorbed $\mathrm{CO}_{2}$ from the atmosphere across the water-air interface, whereas PMR emitted $\mathrm{CO}_{2}$. The main reason for this may be the reduction in phytoplankton biomass in PMR induced by the filter feeding of short-necked clams. Phytoplankton biomass was regarded as a primary factor affecting the $\mathrm{CO}_{2}$ flux because of the consumption of $\mathrm{CO}_{2}$ by phytoplankton through photosynthesis (Xing et al. 2005, 2006, Trolle et al. 2012, Li et al. 2015). In the present study, the mean concentration of chl a during the farming season in PMR was $15.80 \mathrm{mg} \mathrm{m}^{-3}$, which was significantly lower than that in PM $\left(44.50 \mathrm{mg} \mathrm{m}^{-3} ; \mathrm{p}<\right.$ $0.05, t_{4}=-28.636$; Fig. 3). Based on the above findings, short-necked clams might influence the carbon budget of aquaculture systems in several ways. First, filter feeding could reduce the accumulation of organic carbon in the water column and the subsequent organic carbon output via water (Table 3, Fig. 1). Second, filter feeding by clams could indirectly alter the direction of $\mathrm{CO}_{2}$ exchange across the water-air interface (Fig. 2). Third, bioturbation by clam movements could reduce carbon accumulation in the sediment (Table 3). In addition, given that bivalves can use bicarbonate to build up their shells, and this process takes some carbon out of the global carbon cycle, bivalves, therefore, could be regarded as an important part of carbon sink in the global carbon cycle on a long time scale.

It is worth noting that different culturing densities of bivalves could exert different ecological effects. When the biomass of bivalves is abundant, bivalves can exert 'top-down' control on phytoplankton, thereby decreasing the primary production of the

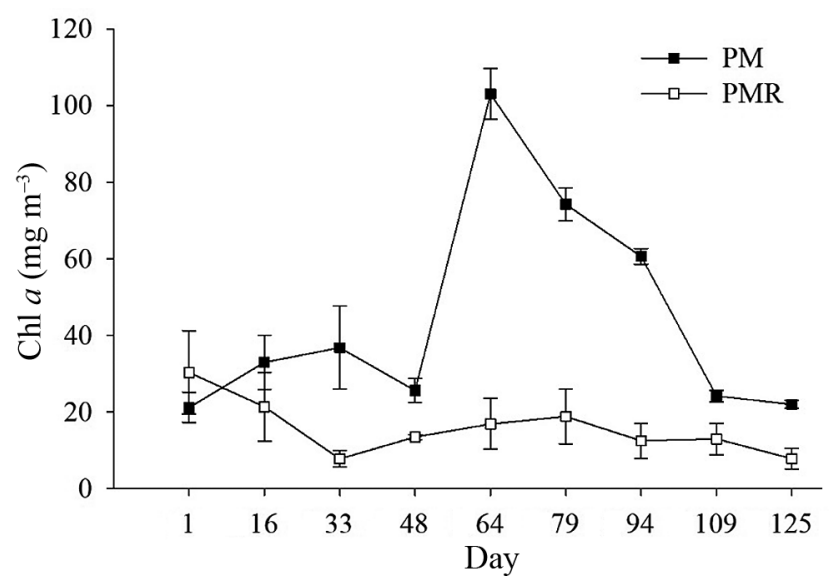

Fig. 3. Variations in chl a concentration in the PM and PMR aquaculture systems (defined in Table 1) during the farming season 
water column (Dame \& Prins 1997, Newell 2004, Prins \& Escaravage 2005, Petersen et al. 2008, Dame 2016). When the density is low, bivalves can exert a 'bottom-up' effect through the promotion of nutrient recycling, and thus promote phytoplankton populations (Ogilvie et al. 2000, Cranford et al. 2007, Froján et al. 2014). Considering that phytoplankton is one of the key factors regulating the direction of the $\mathrm{CO}_{2}$ flux, carbon absorption across the water-air interface as well as carbon sequestration by bivalve shells are likely to both be achieved in aquaculture systems with relatively low stocking densities of bivalves. Thus, in such aquaculture systems, the carbon sink function of aquaculture ponds might be enhanced. Further study is required to determine the suitable bivalves and their appropriate stocking density.

\subsection{Potential roles of aquaculture systems in the global carbon cycle}

Aquaculture systems could play an indispensable role in the global carbon cycle. Previous studies have mainly focused on the water-air interface of aquaculture systems (Chen et al. 2015, 2016), and gaseous carbon emission across the water-air interface can cause a direct effect on the greenhouse gas concentrations in the atmosphere. In the present study, the cGWP value in PM was negative (-63.05, Table 4) over a $20 \mathrm{yr}$ horizon, indicating that the polyculture of crabs and shrimp has the potential to help mitigate the greenhouse effect. Conversely, the cGWP value in PMR was positive (211.41, Table 4), indicating that a tri-species polyculture system of crabs with shrimp and clams would exacerbate global warming. The number of studies on the GWP of aquaculture systems to date is limited. Chen et al. (2016) reported that the cGWP values of a shrimp culture system and a sea cucumbershrimp polyculture system were 33.55 and 47.71 , respectively. Yang et al. (2015) reported that the cGWP value in a polyculture system of shrimp and fish was 238.17. Different aquaculture systems usually have different internal biological and physicochemical characteristics, which could affect the $\mathrm{CO}_{2}$ and $\mathrm{CH}_{4}$ fluxes to a great extent (Thornton 1990). Therefore, the cGWP value often varies in different aquaculture systems.

The cGWP value of all lakes worldwide was calculated to be 1824.40 (Kirschke et al. 2013, Raymond et al. 2013), which is much higher than the value of PMR in the present study and in the aquaculture systems discussed above, suggesting that aquaculture systems might play a weaker role in accelerating global warming compared to that of lakes. Further, the cGWP value of PM was -63.05, which is close to that of the North Sea (-60.4) (Bange et al. 1994, Borges et al. 2006) and the East China Sea (-62.9) (Wang et al. 2000, Zhang et al. 2004), implying that deployment of some aquaculture systems may prove effective in mitigating global warming while harvesting aquaculture organisms.

In addition to that achieved through carbon exchanges across the water-air interface, aquaculture systems can also play important roles in the global carbon cycle by carbon accumulation in sediments. According to Boyd et al. (2010), freshwater and brackish water aquaculture ponds sequester an estimated 71.3 to $249.3 \mathrm{~g} \mathrm{C} \mathrm{m}^{-2}$ globally. In the present study, the annual carbon burial rates in PM and PMR were 7.54 and $2.40 \mathrm{~g} \mathrm{~m}^{-2}$, respectively, which were much lower than those in freshwater and brackish water aquaculture ponds (Boyd et al. 2010), possibly related to differences in aquaculture management such as stocks, feed types, feeding strategies, etc. In comparison to other types of aquatic systems, the carbon burial rates in PM and PMR were much lower than those in global lakes and reservoirs but were close to those in mesotrophic and oligotrophic lakes (Table 5). Unlike lakes and reservoirs that have been inundated for decades or even centuries, pond water is usually drained and sediments are dried annually after harvesting, and even dredged periodically. As a result, a certain portion of organic carbon deposited in the sediments could be mineralized after exposure to the air and sunlight, which might represent unaccounted carbon emission in the present study. Carbon emission from aquaculture ponds during the non-farming season could be $201.59 \mathrm{mg} \mathrm{m}^{-2} \mathrm{~h}^{-1}$ (Yang et al. 2018). Therefore, it is necessary to conduct research on the carbon emission during the nonfarming season in future, which would make the carbon budget as well as the role of aquaculture ponds in the global carbon cycle more precise.

To comprehensively evaluate the role of aquaculture systems in the global carbon cycle, the carbon exchanges across the water-air interface, the carbon accumulation in the sediment and the carbon sequestration through harvested animals should all be taken into account. In this study, PM sequestered $28.95 \mathrm{~g} \mathrm{C}$ $\mathrm{m}^{-2}$ in total during the farming season (Table 5), suggesting that PM acted as a carbon sink. In PMR, although the sediment and the shell formation of the clams sequestered 2.40 and $18.87 \mathrm{~g} \mathrm{C} \mathrm{m}^{-2}$, respectively, during the farming season, PMR made a greater contribution of $53.15 \mathrm{~g} \mathrm{C} \mathrm{m}^{-2}$ to carbon emissions. In total, PMR emitted $31.88 \mathrm{~g} \mathrm{C} \mathrm{m}^{-2}$ during the farming season, which indicated that PMR was a carbon source in the global carbon cycle. 
Table 5. Annual carbon emissions and burial rates in different aquatic systems $\left(\mathrm{g} \mathrm{m}^{-2}\right)$. Positive values in carbon emissions indicate carbon emissions from aquatic systems, while negative values indicate carbon absorption by aquatic systems at the water-air interface. Positive values in carbon sink/source function indicate a carbon source function, while negative values indicate a carbon sink function. ND: no data

\begin{tabular}{|c|c|c|c|c|c|}
\hline Systems & \multicolumn{2}{|c|}{ Carbon emission } & $\begin{array}{c}\text { Carbon } \\
\text { burial }\end{array}$ & $\begin{array}{l}\text { Carbon sink/ } \\
\text { source function }\end{array}$ & Reference \\
\hline \multicolumn{6}{|l|}{ Lakes and reservoirs } \\
\hline Global estimation & 100.00 & 30.53 & 76.67 & 53.86 & $\begin{array}{l}\text { Raymond et al. (2013), } \\
\text { Cole et al. (2007), } \\
\text { Bastviken et al. (2011) }\end{array}$ \\
\hline Lake Donghu & 23.50 & ND & 296.16 & -272.66 & Yang et al. (2008) \\
\hline Lake Frisksjön & 48.65 & ND & 21.41 & 27.24 & Sobek et al. (2006) \\
\hline Chub Lake & 13.50 & ND & 6.01 & 7.49 & Dillon \& Molot (1997) \\
\hline Crosson Lake & 17.50 & ND & 5.10 & 12.40 & Dillon \& Molot (1997) \\
\hline Dickie Lake & 11.70 & ND & 10.10 & 1.60 & Dillon \& Molot (1997) \\
\hline Harp Lake & 7.17 & ND & 6.26 & 0.91 & Dillon \& Molot (1997) \\
\hline Plastic Lake & 8.46 & ND & 2.18 & 6.28 & Dillon \& Molot (1997) \\
\hline \multicolumn{6}{|l|}{ Streams and rivers } \\
\hline Global estimation & 2884.62 & 2.40 & ND & $\begin{array}{l}\mathrm{R} \\
\mathrm{B}\end{array}$ & $\begin{array}{l}\text { Raymond et al. (2013), } \\
\text { Bastviken et al. (2011) }\end{array}$ \\
\hline \multicolumn{6}{|l|}{ Aquaculture ponds } \\
\hline \multicolumn{6}{|l|}{ Seawater ponds } \\
\hline Shrimp pond & -5.69 & 0.57 & ND & - & Chen et al. (2016) \\
\hline Polyculture pond of shrimp with sea cucumbers & 11.23 & 0.068 & ND & - & Chen et al. (2016) \\
\hline Polyculture pond of swimming crabs with shrimp & -21.55 & 0.14 & 7.54 & -28.95 & Present study \\
\hline Polyculture pond of swimming crabs with shrimp and clams & s 53.00 & 0.15 & 2.40 & 31.88 & Present study \\
\hline \multicolumn{6}{|l|}{ Brackish water ponds } \\
\hline Shrimp pond & 76.30 & 73.26 & ND & - & Yang et al. (2015) \\
\hline Polyculture pond of shrimp with fish & -184.28 & 5.03 & ND & - & Yang et al. (2015) \\
\hline
\end{tabular}

Acknowledgements. This study was funded by the National Great Project of Scientific and Technical Supporting Programs (Grant No. 2011BAD13B03), the National Key Research and Development Project (Grant No. 2019YFD0900400), the Programs for Excellent Youth Foundation of Shandong province (Grant No. JQ201009) and Beijing Natural Science Foundation, China (Grant No. 6194036).

\section{LITERATURE CITED}

Adhikari S, Sahu BC, Lal R (2012) Nutrients budget and effluents characteristics in polyculture of scampi (Macrobrachium rosenbergii) and Indian major carps ponds using organic inputs. Water Sci Technol 66: 1540-1548

Alongi DM, Johnston DJ, Xuan TT (2000) Carbon and nitrogen budgets in shrimp ponds of extensive mixed shrimp-mangrove forestry farms in the Mekong Delta, Vietnam. Aquacult Res 31:387-399

Bange H, Bartell U, Rapsomanikis S, Andreae MO (1994) Methane in the Baltic and North Seas and a reassessment of the marine emissions of methane. Global Biogeochem Cycles 8:465-480

Bastviken D, Tranvik LJ, Downing JA, Crill PM, EnrichPrast A (2011) Freshwater methane emissions offset the continental carbon sink. Science 331:50

Bendschneider K, Robinson RJ (1952) A new spectrophotometric method for the determination of nitrite in sea water. J Mar Res 11:87-96
Boltovskoy D, Correa N (2015) Ecosystem impacts of the invasive bivalve Limnoperna fortunei (golden mussel) in South America. Hydrobiologia 746:81-95

Borges A, Schiettecatte LS, Abril G, Delille B, Gazeau F (2006) Carbon dioxide in European coastal waters. Estuar Coast Shelf Sci 70:375-387

Boyd CE, Wood CW, Chaney PL, Queiroz JF (2010) Role of aquaculture pond sediments in sequestration of annual global carbon emissions. Environ Pollut 158:2537-2540

Cai WJ, Dai M, Wang Y (2006) Air-sea exchange of carbon dioxide in ocean margins: a province-based synthesis. Geophys Res Lett 33:L12603

Chen Y, Dong S, Wang Z, Wang F, Gao Q, Tian X, Xiong $\mathrm{Y}$ (2015) Variations in $\mathrm{CO}_{2}$ fluxes from grass carp Ctenopharyngodon idella aquaculture polyculture ponds. Aquacult Environ Interact 8:31-40

* Chen Y, Dong S, Wang F, Gao Q, Tian X (2016) Carbon dioxide and methane fluxes from feeding and no-feeding mariculture ponds. Environ Pollut 212:489-497

Cole JJ, Prairie YT, Caraco NF, McDowell WH and others (2007) Plumbing the global carbon cycle: integrating inland waters into the terrestrial carbon budget. Ecosystems 10:172-185

* Cranford PJ, Strain PM, Dowd M, Hargrave BT, Grant J, Archambault MC (2007) Influence of mussel aquaculture on nitrogen dynamics in a nutrient enriched coastal embayment. Mar Ecol Prog Ser 347:61-78

Dame RF (2016) Ecology of marine bivalves: an ecosystem approach. CRC Press, Boca Raton, FL 
Dame RF, Prins TC (1997) Bivalve carrying capacity in coastal ecosystems. Aquat Ecol 31:409-421

Davis WR (1993) The role of bioturbation in sediment resuspension and its interaction with physical shearing. J Exp Mar Biol Ecol 171:187-200

Nillon PJ, Molot LA (1997) Dissolved organic and inorganic carbon mass balances in central Ontario lakes. Biogeochemistry 36:29-42

" Dixon RK, Solomon AM, Brown S, Houghton RA, Trexier MC, Wisniewski J (1994) Carbon pools and flux of global forest ecosystems. Science 263:185-190

Dong J, Tian XL, Dong SL, Zhang K, Feng J, He RP (2013) Study on nitrogen and phosphorus budget in polyculture systems of Litopenaeus vannamei and Portunus trituberculatus. J Ocean Univ China 43:016-024 (in Chinese with English abstract)

Filgueira R, Byron CJ, Comeau LA, Costa-Pierce B and others (2015) An integrated ecosystem approach for assessing the potential role of cultivated bivalve shells as part of the carbon trading system. Mar Ecol Prog Ser 518:281-287

Fisheries Department of Agriculture Ministry of China (2017) China fisheries statistical yearbook 2017. China Agriculture Press, Beijing (in Chinese)

Forrest BM, Keeley NB, Hopkins GA, Webb SC, Clement DM (2009) Bivalve aquaculture in estuaries: review and synthesis of oyster cultivation effects. Aquaculture 298:1-15

Frankignoulle M (1994) A complete set of buffer factors for acid/base $\mathrm{CO}_{2}$ system in seawater. J Mar Syst 5:111-118

Frankignoulle M, Canon C, Gattuso JP (1994) Marine calcification as a source of carbon dioxide: positive feedback of increasing atmospheric $\mathrm{CO}_{2}$. Limnol Oceanogr 39:458-462

Froján M, Arbones B, Zúñiga D, Castro CG, Figueiras FG (2014) Microbial plankton community in the Ría de Vigo (NW Iberian upwelling system): impact of the culture of Mytilus galloprovincialis. Mar Ecol Prog Ser 498:43-54

Hansen HP, Koroleff F (1999) Determination of nutrients. In: Grasshoff K, Kremling K, Ehrhardt M (eds) Methods of seawater analysis, $3^{\text {rd }}$ edn. Wiley-VCH, Weinheim, p 180-187

Hayakawa K, Sekino T, Yoshioka T, Maruo M, Kumagai M (2003) Dissolved organic carbon and fluorescence in Lake Hovsgol: factors reducing humic content of the lake water. Limnology 4:0025-0033

Holmer M, Duarte CM, Heilskov A, Olesen B, Terrados J (2003) Biogeochemical conditions in sediments enriched by organic matter from net-pen fish farms in the Bolinao area, Philippines. Mar Pollut Bull 46:1470-1479

IPCC (2014) Climate change 2014: mitigation of climate change. Contribution of Working Group III to the Fifth Assessment Report of the Intergovernmental Panel on Climate Change. Cambridge University Press, Cambridge

Kirschke S, Bousquet P, Ciais P, Saunois M and others (2013) Three decades of global methane sources and sinks. Nat Geosci 6:813-823

Le Quéré C, Andrew RM, Friedlingstein P, Sitch S and others (2017) Global carbon budget 2017. Earth Syst Sci Data Discussions 1-79

Li J, Dong S, Gao Q, Fang W, Tian X, Zhang S (2015) Total organic carbon budget of integrated aquaculture system of sea cucumber Apostichopus japonicus, jellyfish Rhopilema esculenta and shrimp Fenneropenaeus chinensis. Aquacult Res 45:1825-1831

Li S, Zhang Q, Bush RT, Sullivan LA (2015) Methane and $\mathrm{CO}_{2}$ emissions from China's hydroelectric reservoirs: a new quantitative synthesis. Environ Sci Pollut Res Int 22: 5325-5339
Muller Karger FE, Varela R, Thunell R, Luerssen R, Hu C, Walsh JJ (2005) The importance of continental margins in the global carbon cycle. Geophys Res Lett 32:L01602

*Murphy J, Riley JP (1962) A modified single solution method for the determination of phosphate in natural waters. Anal Chim Acta 27:31-36

Newell RIE (2004) Ecosystem influences of natural and cultivated populations of suspension-feeding bivalve molluscs: a review. J Shellfish Res 23:51-62

Ogilvie SC, Ross AH, Schiel DR (2000) Phytoplankton biomass associated with mussel farms in Beatrix Bay, New Zealand. Aquaculture 181:71-80

Ortiz-Llorente M, Alvarez-Cobelas M (2012) Comparison of biogenic methane emissions from unmanaged estuaries, lakes, oceans, rivers and wetlands. Atmos Environ 59: 328-337

*Pan Y, Birdsey RA, Fang J, Houghton R and others (2011) A large and persistent carbon sink in the world's forests. Science 333:988-993

* Petersen JK, Hansen JW, Laursen MB, Clausen P, Carstensen J, Conley DJ (2008) Regime shift in a coastal marine ecosystem. Ecol Appl 18:497-510

Prins T, Escaravage V (2005) Can bivalve suspension-feeders affect pelagic food web structure? In: Dame RF, Olenin S (eds) The comparative roles of suspension-feeders in ecosystems. Springer, Dordrecht, p 31-51

* Prins TC, Smaal AC, Dame RF (1997) A review of the feedbacks between bivalve grazing and ecosystem processes. Aquat Ecol 31:349-359

* Raymond PA, Hartmann J, Lauerwald R, Sobek S and others (2013) Global carbon dioxide emissions from inland waters. Nature 503:355-359

Sagi T (1966) Determination of ammonia in sea water by the indophenol method and its application to the coastal and offshore waters. Oceanogr Mag 18:43-51

Sahu BC, Adhikari S, Dey L (2013a) Carbon, nitrogen and phosphorus budget in shrimp (Penaeus monodon) culture ponds in eastern India. Aquacult Int 21: 453-466

* Sahu BC, Adhikari S, Mahapatra AS, Dey L (2013b) Carbon, nitrogen, and phosphorus budget in scampi (Macrobrachium rosenbergii) culture ponds. Environ Monit Assess 185:10157-10166

Sarà G, Scilipoti D, Mazzola A, Modica A (2004) Effects of fish farming waste to sedimentary and particulate organic matter in a southern Mediterranean area (Gulf of Castellammare, Sicily): a multiple stable isotope study $\left(\delta^{13} \mathrm{C}\right.$ and $\delta^{15}$ ). Aquaculture 234:199-213

Shine KP, Fuglestvedt JS, Hailemariam K, Stuber N (2005) Alternatives to the global warming potential for comparing climate impacts of emissions of greenhouse gases. Clim Change 68:281-302

Sobek S, Söderbäck B, Karlsson S, Andersson E, Brunberg AK (2006) A carbon budget of a small humic lake: an example of the importance of lakes for organic matter cycling in boreal catchments. Ambio 35:469-475

Sousa R, Gutiérrez JL, Aldridge DC (2009) Non-indigenous invasive bivalves as ecosystem engineers. Biol Invasions 11:2367-2385

* Stabili L, Acquaviva MI, Cavallo RA (2005) Mytilus galloprovincialis filter feeding on the bacterial community in a Mediterranean coastal area (Northern Ionian Sea, Italy). Water Res 39:469-477

Tang Y, Zhao L, Yang Y, Liu Q, Fan Y, Wu J (2015) Effects of Hyriopsis cumingii, Hypophthalmichthys milotrix and Aristichthys nobilis polyculture on microbial community 
structure in aquaculture ponds/enclosures: a comparative study based on 16S rDNA sequences. Freshw Fish 45:70-77 (in Chinese with English abstract)

Thornton KW (1990) Perspectives on reservoir limnology. In: Thornton KW, Kimmel BL, Payne FE (eds) Reservoir limnology: ecological perspectives. John Wiley \& Sons, New York, NY, p 1-13

Tian X, Li D, Dong S, Yan X, Qi Z, Liu G, Lu J (2001) An experimental study on closed-polyculture of penaeid shrimp with tilapia and constricted tagelus. Aquaculture 202:57-71

* Tranvik LJ, Downing JA, Cotner JB, Loiselle SA and others (2009) Lakes and reservoirs as regulators of carbon cycling and climate. Limnol Oceanogr 54:2298-2314

Trolle D, Staehr PA, Davidson TA, Bjerring R, Lauridsen TL, Søndergaard M, Jeppesen E (2012) Seasonal dynamics of $\mathrm{CO}_{2}$ flux across the surface of shallow temperate lakes. Ecosystems 15:336-347

Vaughn CC, Hakenkamp CC (2001) The functional role of burrowing bivalves in freshwater ecosystems. Freshw Biol 46:1431-1446

*Verdegem MCJ, Bosma RH (2009) Water withdrawal for brackish and inland aquaculture, and options to produce more fish in ponds with present water use. Water Policy 11(Suppl 1):52-68

Wang SL, Chen CTA, Hong GH, Chung CS (2000) Carbon dioxide and related parameters in the East China Sea. Cont Shelf Res 20:525-544

Williamson CE, Overholt EP, Pilla RM, Leach TH and others (2015) Ecological consequences of long-term browning in lakes. Sci Rep 5:18666

WMO (World Meteorological Organization) (2017) The state of greenhouse gases in the atmosphere based on global observations through 2016. WMO Greenhouse Gas Bull No. 13. WMO, Geneva

Editorial responsibility: Alejandro Buschmann, Puerto Montt, Chile
Xia B, Cui Y, Chen B, Cui Z, Qu K, Ma F (2014) Carbon and nitrogen isotopes analysis and sources of organic matter in surface sediments from the Sanggou Bay and its adjacent areas, China. Acta Oceanol Sin 33:48-57

Xing Y, Xie P, Yang H, Ni L, Wang Y, Rong K (2005) Methane and carbon dioxide fluxes from a shallow hypereutrophic subtropical lake in China. Atmos Environ 39:5532-5540

Xing Y, Xie P, Yang H, Wu A, Ni L (2006) The change of gaseous carbon fluxes following the switch of dominant producers from macrophytes to algae in a shallow subtropical lake of China. Atmos Environ 40:8034-8043

Yang H, Xing Y, Xie P, Ni L, Rong K (2008) Carbon source/ sink function of a subtropical, eutrophic lake determined from an overall mass balance and a gas exchange and carbon burial balance. Environ Pollut 151:559-568

* Yang P, He Q, Huang J, Tong C (2015) Fluxes of greenhouse gases at two different aquaculture ponds in the coastal zone of southeastern China. Atmos Environ 115:269-277

* Yang P, Lai DY, Huang JF, Tong C (2018) Effect of drainage on $\mathrm{CO}_{2}, \mathrm{CH}_{4}$, and $\mathrm{N}_{2} \mathrm{O}$ fluxes from aquaculture ponds during winter in a subtropical estuary of China. J Environ Sci (China) 65:72-82

* Zhang D, Tian X, Dong S, Chen Y, Feng J, He RP, Zhang K (2019) Methane fluxes from typical marine polyculture ponds of swimming crab with kuruma shrimp and shortnecked clam in eastern China. Aquacult Environ Interact 11:63-73

* Zhang G, Zhang J, Kang Y, Liu S (2004) Distributions and fluxes of methane in the East China Sea and the Yellow Sea in spring. J Geophys Res Oceans 109:C07011

Zhang K, Tian XL, Dong SL, Feng J, He RP (2016) An experimental study on the budget of organic carbon in polyculture systems of swimming crab with white shrimp and short-necked clam. Aquaculture 451:58-64

Submitted: September 4, 2019; Accepted: January 9, 2020

Proofs received from author(s): March 12, 2020 